TAHKIM, Jurnal Peradaban dan Hukum Islam. Vol.2 No.l (Maret, 2019) | ISSN : 2597-7962

\title{
PENDEKATAN SEJARAH DALAM STUDI ISLAM
}

\author{
Walim \\ Fakultas Hukum Untag Cirebon \\ Walimshmh7@gmail.com
}

\begin{abstract}
ABSTRAK
Pengkajian Islam adalah sebuah disiplin yang sangat tua seumur dengan kemunculan Islam sendiri. Pengkajian Islam dalam sejarah panjangnya mewujud dalam berbagai tipe dan menyediakan lahan yang sangat kaya bagi kegelisahan akademik dari kalangan insider maupun outsider. Jika Studi outsider terwadahi dalam bentuk Orientalisme atau Islamologi, maka kajian insider memunculkan model ngaji yang berorientasi pengamalan, apologis yang memberi counter terhadap orientalisme, Islamisasi ilmu yang berupaya memberikan landasan paradigma Islam bagi ilmu-ilmu sekuler atau studi Islam klasik yang bersifat kritis namun masih berorientasi pada pengamalan. Sebagai objek studi, Islam harus didekati dari berbagai aspeknya dengan menggunakan multidisiplin ilmu pengetahuan untuk mengurai fenomena agama ini. Salah satunya adalah melalui pendekatan sejarah yang tidak dapat diabaikan begitu saja bagi seseorang yang ingin memahami tentang Islam dengan benar.
\end{abstract}

Kata Kunci: Pengkajian, Islam, sejarah.

\begin{abstract}
ABSTRACK
Islamic Studies is a very old discipline as old as the appearance of Islam itself. The study of Islam in its long history manifests itself in various types and provides a very rich land for the academic anxieties of insiders and outsiders. If the outsider study is embodied in the form of Orientalism or Islamology, then the insider study leads to an aphrodite-oriented, apologist model that gives counter to orientalism, the Islamization of science which seeks to lay the foundation of an Islamic paradigm for secular or classical Islamic studies that is critical but still oriented on practice. As the object of study, Islam must be approached from various aspects by using multidisciplinary science to unravel this religious phenomenon. One is through a historical approach that can not be ignored for anyone who wants to understand Islam right.
\end{abstract}

Keywords: Studies, Islam, History. 
TAHKIM, Jurnal Peradaban dan Hukum Islam. Vol.2 No.l (Naret, 2019) | ISSN : 2597-7962

\section{A. PENDAHULUAN}

Islam telah menjadi kajian yang menarik minat banyak kalangan. Studi keislaman pun semakin berkembang. Islam tidak lagi dipahami hanya dalam pengertian historis dan doktriner, tetapi telah menjadi fenomena yang kompleks. Islam tidak hanya terdiri dari rangkaian petunjuk formal tentang bagaimana seorang individu harus memaknai kehidupannya. Islam telah menjadi sebuah sistem budaya, peradaban, komunitas politik, ekonomi dan bagian sah dari perkembangan dunia. Mengkaji dan mendekati Islam, tidak lagi mungkin hanya dari satu aspek, karenanya dibutuhkan metode dan pendekatan interdisipliner.

Kajian agama, termasuk Islam, seperti disebutkan di atas dilakukan oleh sarjana Barat dengan menggunakan ilmu-ilmu sosial dan humanities, sehingga muncul sejarah agama, psikologi agama, sosiologi agama, antropologi agama, dan lain-lain. Dalam perjalanan dan pengembangannya, sarjana Barat bukan hanya menjadikan masyarakat Barat sebagai lapangan penelitiannya, namun juga masyarakat di negara-negara berkembang, yang kemudian memunculkan orientalisme.

Sarjana Barat sebenarnya telah lebih dahulu dan lebih lama melakukan kajian terhadap fenomena Islam dari pelbagai aspek: sosiologis, kultural, perilaku politik, doktrin, ekonomi, perkembangan tingkat pendidikan, jaminan keamanan, perawatan kesehatan, perkembangan minat dan kajian intelektual, dan seterusnya.

Sementara itu, agama atau keagamaan sebagai sistem kepercayaan dalam kehidupan umat manusia dapat dikaji melalui berbagai sudut pandang. Islam khususnya, sebagai agama yang telah berkembang selama empatbelas abad lebih menyimpan banyak banyak masalah yang perlu diteliti, baik itu menyangkut ajaran dan pemikiran kegamaan maupun realitas sosial, politik, ekonomi dan budaya. Salah satu sudut pandang yang dapat dikembangkankan bagi pengkajian Islam itu adalah pendekatan sejarah. Berdasarkan sudut pandang tersebut, Islam dapat dipahami dalam berbagai dimensinya. Betapa banyak persoalan umat Islam hingga dalam perkembangannya sekarang, bisa dipelajari dengan berkaca kepada peristiwaperistiwa masa lampau, sehingga segala kearifan masa lalu itu memungkinkan untuk dijadikan alternatif rujukan di dalam menjawab persoalan-persoalan masa kini. Di sinilah arti pentingnya sejarah bagi umat Islam pada khususnya, apakah 
TAHKIM, Jurnal Peradaban dan Hukum Islam. Vol.2 No.l (Maret, 2019) | ISSN : 2597-7962

sejarah sebagai pengetahuan ataukah ia dijadikan pendekatan didalam mempelajari agama.

Bila sejarah dijadikan sebagai sesuatu pendekatan untuk mempelajari agama, maka sudut pandangnya akan dapat membidik aneka-ragam peristiwa masa lampau. Sebab sejarah sebagai suatu metodologi menekankan perhatiannya kepada pemahaman berbagai gejala dalam dimensi waktu. Aspek kronologis sesuatu gejala, termasuk gejala agama atau keagamaan, merupakan ciri khas di dalam pendekatan sejarah. Karena itu penelitian terhadap gejala-gejala agama berdasarkan pendekatan ini haruslah dilihat segi-segi prosesnya dan perubahan-perubahannya. Bahkan secara kritis, pendekatan sejarah itu bukanlah sebatas melihat segi pertumbuhan, perkembangan serta keruntuhan mengenai sesuatu peristiwa, melainkan juga mampu memahami gejala-gejala struktural yang menyertai peristiwa. Inilah pendekatan sejarah yang sesungguhnya perlu dikembangkan di dalam penelitian masalah-masalah agama.

\section{B. PEMBAHASAN}

\section{Studi Islam sebagai Disiplin Ilmu}

Munculnya istilah Studi Islam, yang di dunia Barat dikenal dengan istilah Islamic Studies, dalam dunia Islam dikenal dengan Dirasah Islamiyah, sesungguhnya telah didahului oleh adanya perhatian besar terhadap disiplin ilmu agama yang terjadi pada abad ke sembilan belas di dunia Barat. Perhatian ini di tandai dengan munculnya berbagai karya dalam bidang keagamaan, seperti: buku Intruduction to The Science of Relegion karya F. Max Muller dari Jerman (1873); Cernelis P. Tiele (1630-1902), P.D. Chantepie de la Saussay (1848-1920) yang berasal dari Belanda. Inggris melahirkan tokoh Ilmu Agama seperti E. B. Taylor (1838-1919). Perancis mempunyai Lucian Levy Bruhl (1857-1939), Louis Massignon (w. 1958) dan sebagainya. Amirika menghasilkan tokoh seperti William James (1842-1910) yang dikenal melalui karyanya The Varieties of Relegious Experience (1902). Eropa Timur menampilkan Bronislaw Malinowski (1884-1942) dari Polandia, Mircea Elaide dari Rumania. Itulah sebagian nama yang dikenal dalam dunia ilmu agama, walaupun tidak seluruhnya dapat penulis sebutkan di sini. 
TAHKIM, Jurnal Peradaban dan Hukum Islam. Vol.2 No.l (Maret, 2019) | ISSN : 2597-7962

Tidak hanya di Barat, di Asia pun muncul beberapa tokoh Ilmu Agama. Di Jepang muncul J. Takakusu yang berjasa memperkenalkan Budhisme pada penghujung abad kesembilan belas dan T. Suzuki dengan sederaetan karya ilmiahnya tentang Zen Budhisme. India mempunyai S Radhakrishnan selaku pundit Ilmu Agama maupun filsafat India, Moses D. Granaprakasam, Religious Truth an relation between Religions (1950), dan P. D. Devanadan, penulis The Gospel and Renascent Hinduism, yang diterbitkan di London pada 1959. dan filsafat analitis. ${ }^{1}$

Berbeda dengan dunia Barat, Ilmu Agama (baca: Studi Islam) di dunia Islam telah lama muncul. Dalam dunia Islam dikenal beberapa tokoh dalam berbagai disiplin ilmu. Dalam bidang yurisprudensi (hukum) dikenal tokoh seperti Abu Hanifah, Al-Syafi'I, Malik, dan Ahmad bin Hanbal. Dalam bidang ilmu Tafsir dikenal tokoh seperti Al-Thabary, Ibn Katsir, Al-Zamahsyari, dan sebagainya pada sekitar abad kedua dan keempat hijriyah. Dan akhirnya muncul tokoh-tokoh abad kesembilan belas seperti: Muhammad Abduh, Rasyid Ridha, dan Abad kedua puluh seperti Musthafa al-Maraghy, penulis Tafsir al-Maraghy. Di bidang kalam pun muncul tokh-tokoh besar dari berbagai aliran: Khawarij, Murji'ah, Syi'ah, Asy’ariyah, dan Mu'tazilah. Penulis bidang ini antara lain; al-Qadhi Abdul Jabbar, penulis al-Mughny dan Syarah al-Ushul al-Khamsah (w. 415 H). Di bidang Tasawuf melahirkan tokoh-tokoh seperti al-qusyairi yang terkenal dengan Kitabnya Al-Risalah al-Qusyairiyah (w. 456), Abu Nasr al-Sarraj al-Thusy (w. 378 H), penulis al-Luma', Al-Kalabadzi, penulis al-ta'arruf li Madzhab Ahl al-Tashawwuf, Abdul Qadir al-Jailany, penulis kitan Sirr al-Asrar, al-Fath al-Rabbaniy, dan sebagainya. $^{2}$

Walaupun secara realitas studi ilmu agama (baca: studi Islam [agama]) keberadaannya tidak terbantahkan, tetapi dikalangan para ahli masih terdapat perdebatan di sekitar permasalahan studi Islam dapat dimasukkan ke dalam bidang ilmu pengetahuan atau tidak, mengingat sifat dan karakteristik antara ilmu pengetahuan dan agama berbeda. Pembahasan di sekitar permasalahan ini banyak dikemukakan oleh para pemikir Islam dewasa ini. Amin Abdullah misalnya

1 W.B. Sidjabat, Penelitian Agama: Pendekatan dari Ilmu Agama”, dalam Mulyanto Sumardi (ed.), Penelitian Agama, (Jakarta: Sinar Harapan, 1982), hlm. 70-74.

2 Juhaya S. Praja, Filsafat dan Metodologi Ilmu dalam Islam dan Penerapannya di Indonesia, (Jakarta: Teraju, 2002), hlm. 21. 
TAHKIM, Jurnal Peradaban dan Hukum Islam. Vol.2 No.l (Maret, 2019) | ISSN : 2597-7962

mengatakan jika penyelenggaraan dan penyampaian Islamic Studies, Studi Islam, atau Dirasah Islamiyah hanya mendengarkan dakwah keagamaan di kelas, lalu apa bedanya dengan kegiatan pengajian dan dakwah yang sudah ramai diselenggarakan di luar bangku sekolah? Merespon sinyalemen tersebut menurut Amin Abdullah, pangkal tolak kesulitan pengembangan wilayah kajian studi Islam atau Dirasah Islamiyah berakar pada kesukaran seorang agamawan untuk membedakan antara yang bersifat normatif dan histories. Pada tataran normatif kelihatan Islam kurang sesuai jika dikatakan sebagai disiplin ilmu, sedangkan untuk tataran histories nampaknya relevan.

Tidak hanya kesukaran yang dihadapi oleh seorang agamawan saja, melainkan dosen dan guru juga mengalami hal yang sama. Banyak dijumpai seorang guru atau dosen yang tidak mengerti fungsi dan substansi mata pelajaran atau mata kuliah yang diajarkan. Sehingga banyak murid atau mahasiswa yang tidak memahami apa yang mereka pelajari, sungguh ironis.

Pada tataran normativitas studi Islam agaknya masih banyak terbebani oleh misi keagamaan yang bersifat memihak, romantis, dan apologis, sehingga kadar muatan analisis, kritis, metodologis, historis, empiris, terutama dalam menelaah teks-teks atau naskah-naskah produk sejarah terdahulu kurang begitu ditonjolkan, kecuali dalam lingkungan para peneliti tertentu yang masih sangat terbatas. $^{3}$

Dengan demikian secara sederhana dapat ditemukan jawabannya bahwa dilihat dari segi normatif sebagaimana yang terdapat dalam al-Qur'an dan Hadits, maka Islam lebih merupakan agama yang tidak dapat diberlakukan kepadanya paradigma ilmu ilmu pengetahuan yaitu paradigma analitis, kiritis, metodologis, historis, dan empiris. Sebagai agama, Islam lebih bersifat memihak, romantis, apologis, dan subyektif. Sedangkan jika dilihat dari segi historis, yakni Islam dalam arti yang dipraktekkan oleh manusia serta tumbuh dan berkembang dalam kehidupan manusia, maka Islam dapat dikatakan sebagai sebuah disiplin ilmu, yakni Ilmu Ke-Islaman, Islamic Studies, atau Dirasah Islamiyah.

3 Amin Abdullah, Studi Agama Normativitas atau Historisitas, (Yogyakarta: Pustaka Pelajar, 1996), hlm. 106. 
TAHKIM, Jurnal Peradaban dan Hukum Islam. Vol.2 No.l (Maret, 2019) | ISSN : 2597-7962

Perbedaan dalam melihat Islam yang demikian itu dapat menimbulkan perbedaan dalam menjelaskan Islam itu sendiri. Ketika Islam dilihat dari sudut normatif, maka Islam merupakan agama yang di dalamnya berisi ajaran Tuhan yang berkaitan dengan urusan akidah dan mu'amalah. Sedangkan ketika Islam dilihat dari sudut sejarah atau sebagaimana yang nampak dalam masyarakat, maka Islam tampil sebagai sebuah disiplin ilmu (Islamic Studies).

Selanjutnya studi Islam sebagaimana yang dikemukakan di atas, berbeda pula dengan apa yang disebut sebagai Sains Islam. Sains Islam sebagaimana yang dikemukakan oleh Sayyed Husen Nasr adalah sains yang dikembangkan oleh kaum muslimin sejak abad kedua hijriyah, seperti kedokteran, astronomi, dan lain sebagainya. $^{4}$

Dengan demikian sains Islam mencakup berbagai pengetahuan modern yang dibangun atas arahan nilai-nilai Islami. Sementara studi Islam adalah pengetahuan yang dirumuskan dari ajaran Islam yang dipraktekkan dalam sejarah dan kehidupan manusia. Sedangkan pengetahuan agama adalah pengetahuan yang sepenuhnya diambil dari ajaran-ajaran Allah dan Rasulnya secara murni tanpa dipengaruhi oleh sejarah, seperti ajaran tentang akidah, ibadah, membaca al-Qur'an dan akhlak.

Berdasarkan uraian di atas, berkenaan dengan Studi Islam sebagai sebuah disiplin ilmu tersendiri sangat terkait erat dengan persoalan metode dan pendekatan yang akan dipakai dalam melakukan pengkajian terhadapnya. Inilah yang menjadi topik utama dalam kajian makalah ini.

Metode dan pendekatan dalam Studi Islam mulai diperkenalkan oleh para pemikir Muslim Indonesia sekita tahun 1998 dan menjadi mejadi matakuliah baru dengan nama Metodologi Studi Islam (MSI) yang diajarkan di lingkup Perguruan Tinggi Agama Islam di Indonesia.

\section{Pertumbuhan dan Obyek Studi Islam}

Studi Islam, pada masa-masa awal, terutama masa Nabi dan sahabat, dilakukan di Masjid. Pusat-pusat studi Islam sebagaimana yang dikatakan oleh

\footnotetext{
${ }^{4}$ Syed Husen Nasr, Menjelajah Dunia Modern, (terj.) Hasti Tarekat, dari judul asli $A$ Young Muslim's Guide in The Modern World, (Bandung: Mizan, 1995), hlm. 93.
} 
TAHKIM, Jurnal Peradaban dan Hukum Islam. Vol.2 No.l (Maret, 2019) | ISSN : 2597-7962

Ahmad Amin, Sejarawan Islam kontemporer, berada di Hijaz berpusat Makkah dan Madinah; Irak berpusat di Basrah dan Kufah serta Damaskus. Masing-masing daerah diwakili oleh sahabat ternama. ${ }^{5}$

Pada masa keemasan Islam, pada masa pemerintahan Abbasiyah, studi Islam di pusatkan di Baghdad, Bait al-Hikmah. Sedangkan pada pemerintahan Islam di Spanyol di pusatkan di Universitas Cordova pada pemerintahan Abdurrahman III yang bergelar Al-Dahil. Di Mesir berpusat di Universitas al-Azhar yang didirikan oleh Dinasti Fathimiyah dari kalangan Syi'ah.

Studi Islam sekarang berkembang hampir di seluruh negara di dunia, baik Islam maupun yang bukan Islam. Di Indonesia studi Islam dilaksanakan di UIN, IAIN, STAIN. Ada juga sejumlah Perguruan Tinggi Swasta yang menyelengggarakan Studi Islam seperti Unissula (Semarang) dan Unisba (Bandung).

Studi Islam di negara-negara non Islam diselenggarakan di beberapa negara, antara lain di India, Chicago, Los Angeles, London, dan Kanada. Di Aligarch University India, Studi Islam di bagi mnjadi dua: Islam sebagai doktrin di kaji di Fakultas Ushuluddin yang mempunyai dua jurusan, yaitu Jurusan Madzhab Ahli Sunnah dan Jurusan Madzhab Syi'ah. Sedangkan Islam dari Aspek sejarah di kaji di Fakultas Humaniora dalam jurusan Islamic Studies. Di Jami'ah Millia Islamia, New Delhi, Islamic Studies Program di kaji di Fakultas Humaniora yang membawahi juga Arabic Studies, Persian Studies, dan Political Science.

Di Chicago, Kajian Islam diselenggarakan di Chicago University. Secara organisatoris, studi Islam berada di bawah Pusat Studi Timur Tengah dan Jurusan Bahasa, dan Kebudayaan Timur Dekat. Dilembaga ini, kajian Islam lebih mengutamakan kajian tentang pemikiran Islam, Bahasa Arab, naskah-naskah klasik, dan bahasa-bahasa non-Arab.

Di Amerika, studi Islam pada umumnya mengutamakan studi sejarah Islam, bahasa-bahasa Islam selain bahasa Arab, sastra dan ilmu-ilmu sosial. Studi Islam di Amerika berada di bawah naungan Pusat Studi Timur Tengah dan Timur Dekat.

\footnotetext{
${ }^{5}$ Ahmad Amin, Dhuha al-Islam, (Mesir: Dar al-Kutub al-Ilmiyyah, T.th). hlm. 86.
} 
TAHKIM, Jurnal Peradaban dan Hukum Islam. Vol.2 No.l (Naret, 2019) | ISSN : 2597-7962

Di UCLA, studi Islam dibagi menjadi empat komponen. Pertama, doktrin dan sejarah Islam; kedua, bahasa Arab; ketiga, ilmu-ilmu social, sejarah, dan sosiologi. Di London, studi Islam digabungkan dalam School of Oriental and African Studies (Fakultas Studi Ketimuran dan Afrika) yang memiliki berbagai jurusan bahasa dan kebudayaan di Asia dan Afrika. ${ }^{6}$

Dengan demikian obyek studi Islam dapat dikelompokkan menjadi beberapa bagian, yaitu, sumber-sumber Islam, doktrin Islam, ritual dan institusi Islam, Sejarah Islam, aliran dan pemikiran tokoh, studi kawasan, dan bahasa.

\section{Metode dan Pendekatan Sejarah dalam Studi Islam}

Jika disepakati bahwa Studi Islam (Islamic Studies) menjadi disiplin ilmu tersendiri. Maka telebih dahulu harus di bedakan antara kenyataan, pengetahuan, dan ilmu.

Setidaknya ada dua kenyataan yang dijumpai dalam hidup ini. Pertama, kenyataan yang disepakati (agreed reality), yaitu segala sesuatu yang dianggap nyata karena kita bersepakat menetapkannya sebagai kenyataan; kenyataan yang dialami orang lain dan kita akui sebagai kenyataan. Kedua, kenyataan yang didasarkan atas pengalaman kita sendiri (experienced reality). Berdasarkan adanya dua jenis kenyataan itu, pegetahuan pun terbagi menjadi dua macam; pengetahuan yang diperoleh melalui persetujuan dan pengetahuan yang diperoleh melalui pengalaman langsung atau observasi. Pengetahuan pertama diperoleh dengan cara mempercayai apa yang dikatakan orang lain karena kita tidak belajar segala sesuatu melalui pengalaman kita sendiri. ${ }^{7}$

Bagaimanapun beragamnya pengetahuan, tetapi ada satu hal yang mesti diingat, bahwa setiap tipe pengetahuan mengajukan tuntutan (claim) agar orang membangun 'apa yang diketahui' menjadi sesuatu yang sahih (valid) atau benar (true).

Kesahihan pengetahuan benyak bergantung pada sumbernya. Ada dua sumber pengetahuan yang kita peroleh melalui agreement: tradisi dan autoritas.

\footnotetext{
6 Atang Abdul Hakim, \& Jaih Mubarok, Metodologi Studi Islam, (Bandung: Rosda Karya, 2000), hlm. 12.

${ }^{7}$ Earl Babbie, The Practice of Social Research, (California: Wadasworth Publishing Co., 1986), hlm. 5
} 
TAHKIM, Jurnal Peradaban dan Hukum Islam. Vol.2 No.l (Maret, 2019) | ISSN : 2597-7962

Sumber tradisi adalah pengetahuan yang diperoleh melalui warisan atau transmisi dari generasi ke generasi (al-tawatur). Sumber pengetahuan kedua adalah autoritas (authority), yaitu pengetahuan yang dihasilkan melalui penemuan-penemuan baru oleh mereka yang mempunyai wewenang dan keahlian di bidangnya. Penerimaan autoritas sebagai pengetahuan bergantung pada status orang yang menemukannya atau menyampaikannya.

Berbeda dengan pengetahuan, ilmu dalam arti science menawarkan dua bentuk pendekatan terhadap kenyataan (reality), baik agreed reality maupun experienced reality, melalui penalaran personal, yaitu pendekatan khusus untuk menemukan kenyataan itu. Ilmu menawarkan pendekatan khusus yang disebut metodologi, yaitu ilmu untuk mengetahui.

Metode terbaik untuk memperoleh pengetahuan adalah metode ilmiah (scientific method). Untuk memahami metode ini terlebih dahulu harus dipahami pengertian ilmu. Ilmu dalam arti science dapat dibedakan dengan ilmu dalam arti pengetahuan (knowledge). Ilmu adalah pengetahuan yang sistematik. Ilmu mengawali penjelajahannya dari pengalaman manusia dan berhenti pada batas pengalaman itu. Ilmu dalam pengertian ini tidak mempelajari ihwal surga maupun neraka karena keduanya berada diluar jangkauan pengalaman manusia. Demikian juga mengenai keadaan sebelum dan sesudah mati, tidak menjadi obyek penjelajahan ilmu. Hal-hal seperti ini menjadi kajian agama. Namun demikian, pengetahuan agama yang telah tersusun secara sistematik, terstruktur, dan berdisiplin, dapat juga dinyatakan sebagai ilmu agama.

Menurut Ibnu Taimiyyah ilmu apapun mempunyai dua macam sifat: tabi' dan matbu'. Ilmu yang mempunyai sifat yang pertama ialah ilmu yang keberadaan obyeknya tidak memerlukan pengetahuan si subyeknya tentang keberadaan obyek tersebut. Sifat ilmu yang kedua, ialah ilmu yang keberadaan obyeknya bergantung pada pengetahuan dan keinginan si subyek.

Berdasarkan teori ilmu di atas, ilmu di bagi kepada dua cabang besar. Pertama ilmu tentang Tuhan, dan kedua ilmu tentang makhluk-makhluk ciptaan Tuhan. Ilmu pertama melahirkan ilmu kalam atau teology, dan ilmu kedua melahirkan ilmu-ilmu tafsir, hadits, fiqh, dan metodologi dalam arti umum. Ilmu- 
TAHKIM, Jurnal Peradaban dan Hukum Islam. Vol.2 No.l (Maret, 2019) | ISSN : 2597-7962

ilmu kealaman dengan menggunakan metode ilmiah termasuk kedalam cabang ilmu kedua ilmu ini.

Ilmu pada kategori kedua, menurut Ibnu Taimiyyah dapat dipersamakan dengan ilmu menurut pengertian para pakar ilmu modern, yakni ilmu yang didasarkan atas prosedur metode ilmiah dan kaidah-kaidahnya. Yang dimaksud metode di sini adalah cara mengetahui sesuatu dengan langkah-langkah yang sistematik. Sedangkan kajian mengenai kaidah-kaidah dalam metode tersebut disebut metodologi. Dengan demikian metode ilmiah sering dikenal sebagai proses logico-hipotetico-verifikasi yang merupakan gabungan dari metode deduktif dan induktif. Dalam kontek inilah ilmu agama dalam Studi Islam (Islamic Studies) yang menjadi disiplin ilmu tersendiri, harus dipelajari dengan menggunakan prosedur ilmiah. Yakni harus menggunakan metode dan pendekatan yang sistematis, terukur menurut syarat-syarat ilmiah.

Dalam studi Islam dikenal adanya beberapa metode yang dipergunakan dalam memahami Islam. Penguasaan dan ketepatan pemilihan metode tidak dapat dianggap sepele. Karena penguasaan metode yang tepat dapat menyebabkan seseorang dapat mengembangkan ilmu yang dimilikinya. Sebaliknya mereka yang tidak menguasai metode hanya akan menjadi konsumen ilmu, dan bukan menjadi produsen. Oleh karenanya disadari bahwa kemampuan dalam menguasai materi keilmuan tertentu perlu diimbangi dengan kemampuan di bidang metodologi sehingga pengetahuan yang dimilikinya dapat dikembangkan.

Diantara metode studi Islam yang pernah ada dalam sejarah, secara garis besar dapat dibagi menjadi dua. Pertama, metode komparasi, yaitu suatu cara memahami agama dengan membandingkan seluruh aspek yang ada dalam agama Islam tersebut dengan agama lainnya. Dengan cara yang demikian akan dihasilkan pemahaman Islam yang obyektif dan utuh. Kedua metode sintesis, yaitu suatu cara memahami Islam yang memadukan antara metode ilmiah dengan segala cirinya yang rasional, obyektif, kritis, dan seterusnya dengan metode teologis normative. Metode ilmiah digunakan untuk memahami Islam yang nampak dalam kenyataan histories, empiris, dan sosiologis. Sedangkan metode teologis normative digunakan untuk memahami Islam yang terkandung dalam kitab suci. Melalui metode teologis normative ini seseorang memulainya dari meyakini Islam sebagai agama agama 
TAHKIM, Jurnal Peradaban dan Hukum Islam. Vol.2 No.l (Maret, 2019) | ISSN : 2597-7962

yang mutlak benar. Hal ini di dasarkan kerena agama berasal dari Tuhan, dan apa yang berasal dari Tuhan mutlak benar, maka agamapun mutlak benar. Setelah itu dilanjutkan dengan melihat agama sebagaimana norma ajaran yang berkaitan dengan berbagai aspek kehidupan manusia yang secara keseluruhan diyakini amat ideal. $^{8}$

Metode-metode yang digunakan untuk memahami Islam itu suatu saat mungkin dpandang tidak cukup lagi, sehingga diperlukan adanya pendekatan baru yang harus terus digali oleh para pembaharu. Dalam konteks penelitian, pendekatan-pendekatan (approaches) ini tentu saja mengandung arti satuan dari teori, metode, dan teknik penelitian. Terdapat banyak pendekatan yang digunakan dalam memahami agama. Diantaranya adalah pendekatan teologis normatif, antropologis, sosiologis, psikologis, histories, kebudayaan, dan pendekatan filodofis. Adapun pendekatan yang dimaksud di sini (bukan dalam konteks penelitian), adalah cara pandang atau paradigma yang terdapat dalam satu bidang ilmu yang selanjutnya digunakan dalam memahami agama. Dalam hubungan ini, Jalaluddin Rahmat, menandasakan bahwa agama dapat diteliti dengan menggunakan berbagai paradigma. Realitas keagamaan yang diungkapkan mempunyai nilai kebenaran sesuai dengan kerangka paradigmanya. Karena itu tidak ada persoalan apakah penelitian agama itu penelitian ilmu social, penelitian filosofis, atau penelitian legalistic. ${ }^{9}$

Mengenai banyaknya pendekatan ini, penulis tidak akan menguraikan secara keseluruhan pendekatan yang ada, melaikan hanya pendekatan histories sesuai dengan judul di atas, yakni pendekatan histories.

Sejarah atau histories adalah suatu ilmu yang di dalamnya dibahas berbagai peristiwa dengan memperhatikan unsure tempat, waktu, obyek, latar belakang, dan pelaku dari peristiwa tersebut. Menurut ilmu ini segala peristiwa

\footnotetext{
${ }^{8}$ Abudin Nata, Metodologi Studi Islam, (Jakarta: PT. Raja Grafindo Persada, 1998), hlm. $112-113$

9 Taufik Abdullah dan M Rusli Karim (ed.), Metodologi Penelitian Agama Sebuah Pengantar, (Yogyakarta; Tiara Wacana Yogyakarta, 1990), hlm. 92.
} 
TAHKIM, Jurnal Peradaban dan Hukum Islam. Vol.2 No.l (Maret, 2019) | ISSN : 2597-7962

dapat dilacak dengan melihat kapan peristiwa itu terjadi, di mana, apa sebabnya, siapa yang terlibat dalam peristiwa tersebut. ${ }^{10}$

Melalui pendekatan sejarah seorang diajak menukik dari alam idealis ke alam yang bersifat emiris dan mendunia. Dari keadaan ini seseorang akan melihat adanya kesenjangan atau keselarasan antara yang terdapat dalam alam idealis dengan yang ada di alam empiris dan histories.

Pendekatan kesejarahan ini amat dibutuhkan dalam memahami agama, karena gama itu sendiri turun dalam situasi yang konkret bahkan berkaitan dengan kondisi social kemasyarakatan. Dalam hubungan ini Kuntowijoyo telah melakukan studi yang mendalam terhadap agama yang dalam hal ini Islam, menurut pendekatan sejarah. Ketika ia mempelajari al-Qur'an ia sampai pada satu kesimpulan bahwa pada dasarnya kandungan al-Qur'an itu terbagi menjadi dua bagian. Bagian pertama, berisi konsep-konsep, dan bagian kedua berisi kisah-kisah sejarah dan perumpamaan.

Dalam bagian pertama yang berisi konsep ini kita mendapati banyak sekali istilah al-Qur'an yang merujuk kepada pengertian-pengertian normative yang khusus, doktrin-doktrin etik, aturan-aturan legal, dan ajaran-ajaran keagamaan pada umumnya. Istilah-istilah atau singkatnya pernyataan-pernyataan itu mungkin diangkat dari konsep-konsep yang telah dikenal oleh masyarakat Arab pada waktu al-Qur'an, atau bias jadi merupakan istilah-istilah baru yang dibentuk untuk mendukung adanya konsep-konsep relegius yang ingin diperkenalkannya. Yang jelas istilah itu kemudian dintegrasikan ke dalam pandangan dunia al-Qur'an, dan dengan demikian, lalu menjadi konsep-konsep yang otentik.

Dalam bagian pertama ini, kita mengenal banyak sekali konsep baik yang bersifat abstrak maupun konkret. Konsep tentang Allah, Malaikat, Akherat, ma'ruf, munkar, dan sebagainya adalah termasuk yang abstrak. Sedangkan konsep tentang fuqara', masakin, termasuk yang konkret.

Selanjutnya, jika pada bagian yang berisi konsep, al-Qur'an bermaksud membentuk pemahaman yang komprehensif mengenai nilai-nilai Islam, maka pada bagian yang kedua yang berisi kisah dan perumpamaan, al-Qur'an ingin mengajak

10 Taufik Abdullah, (ed.), Sejarah dan Masyarakat, (Jakarta; Pustaka Firdaus, 1987), hlm. 105 . 
TAHKIM, Jurnal Peradaban dan Hukum Islam. Vol.2 No.l (Maret, 2019) | ISSN : 2597-7962

dilakukannya perenungan untuk memperoleh hikmah. ${ }^{11}$ Melalui pendekatan sejarah ini seseorang diajak untuk memasuki keadaan yang sebenarnya berkenaan dengan penerapan suatu peristiwa. Dari sini maka seseorag tidak akan memahami agama keluar dari konteks historisnya. Seseorang yang ingin memahami al-Qur'an secara benar misalnya, yang bersangkutan harus memahami sejarah turunnya al-Qur'an atau kejadian-kejadian yang mengiringi turunnya al-Qur'an yang selanjutnya disebut dengan ilmu asbab al-nuzul yang pada intinya berisi sejarah turunnya ayat al-Qur'an. Dengan ilmu ini seseorang akan dapat mengetahui hikmah yang terkadung dalam suatu ayat yang berkenaan dengan hokum tertentu, dan ditujukan untuk memelihara syari'at dari kekeliruan memahaminya.

\section{SIMPULAN}

Islamic Studies merupakan sebuah disiplin ilmu yang sangat tua seumur dengan kemunculan Islam sendiri. Islam dalam sejarah panjangnya mewujud dalam berbagai tipe dan menyediakan lahan yang sangat kaya bagi kegelisahan akademik dari kalangan ilmuan baik dari kalangan muslim atau non muslim. Jika Studi outsider terwadahi dalam bentuk Orientalisme atau Islamologi, maka kajian insider memunculkan model ngaji yang berorientasi pengamalan, apologis yang memberi counter terhadap orientalisme, Islamisasi ilmu yang berupaya memberikan landasan paradigma Islam bagi ilmu-ilmu sekuler atau studi Islam klasik yang bersifat kritis namun masih berorientasi pada pengamalan.

Sebagai objek studi, Islam harus didekati dari berbagai aspeknya dengan menggunakan multidisiplin ilmu pengetahuan untuk mengurai fenomena agama ini. Salah satunya adalah melalui pendekatan sejarah yang tidak dapat diabaikan begitu saja bagi seseorang yang ingin memahami tentang Islam dengan benar.

11 Abudin Nata, Metodologi Studi Islam, (Jakarta: PT. Raja Grafindo Persada, 1998), hlm. 48 
TAHKIM, Jurnal Peradaban dan Hukum Islam. Vol.2 No.l (Maret, 2019) | ISSN : 2597-7962

\section{DAFTAR PUSTAKA}

Abdullah, M. Amin, (1996). Studi Agama Normativitas atau Historisitas, Yogyakarta; Pustaka Pelajar.

Abdullah, Taufik dan M Rusli Karim, (ed.), (1990). Metodologi Penelitian Agama Sebuah Pengantar, Yogyakarta; Tiara Wacana Yogyakarta.

Abdullah, Taufik, (ed.), (1987). Sejarah dan Masyarakat, Jakarta; Pustaka Firdaus.

Amin, Ahmad, (t.th), Dhuha al-Islam, Mesir: Dar al-Kutub al-Ilmiyyah.

Babbie, Earl, (1986). The Practice of Social Research, California: Wadasworth Publishing Co.

Hakim, Atang Abdul, dan Jaih Mubarok, (2000). Metodologi Studi Islam, Bandung: Rosda.

Nata, Abudin Nata, (1998). Metodologi Studi Islam, Jakarta: PT. Raja Grafindo Persada.

Praja, Juhaya S., (2002). Filsafat dan Metodologi Ilmu dalam Islam dan Penerapannya di Indonesia, Jakarta: Teraju.

Sayyed Husen Nasr, Menjelajah Dunia Modern, (terj.) (1995). A Young Muslim's Guide in The Modern World, Bandung: Mizan.

Sumardi, Mulyanto, (ed.), (1982). Penelitian Agama, Jakarta: Sinar Harapan. 